\title{
Macular hole formation following panretinal photocoagulation in proliferative diabetic retinopathy
}

\author{
Vinod Kumar, Abhidnya Surve 지 , Sudip Mondal, Shorya Vardhan Azad
}

Dr R.P. Center for Ophthalmic Sciences, All India Institute of Medical Sciences, New Delhi, India

\section{Correspondence to Dr Vinod Kumar; drvinod_agg@yahoo.com}

Accepted 21 January 2021

\section{DESCRIPTION}

A 61-year-old woman with diabetes mellitus and hypertension presented with both eyes (OU) floaters. The best corrected visual acuity (BCVA) was 20/30 OU. Anterior segment OU showed grade 2 nuclear sclerosis and fundus revealed proliferative diabetic retinopathy (PDR). Further work-up revealed right eye (OD) vitreomacular traction (VMT), mild cystoid macular oedema on optical coherence tomography (OCT, figure 1A) and highrisk PDR (figure 1B). After informed consent, she underwent OD panretinal photocoagulation (PRP) in two sittings 2 weeks apart. After 1 month, she presented with sudden drop in OD vision (BCVA 20/200). Fundus examination revealed development of fibrous tissue and regression of retinal neovascularisation (figure 1C). OCT showed full thickness macular hole (FTMH, figure 1D). After informed consent, she underwent combined phacoemulsification and 25-gauge pars plana vitrectomy, removal of fibrous membranes, brilliant blue assisted internal limiting membrane peeling and $20 \%$ sulphur hexafluoride gas tamponade 1

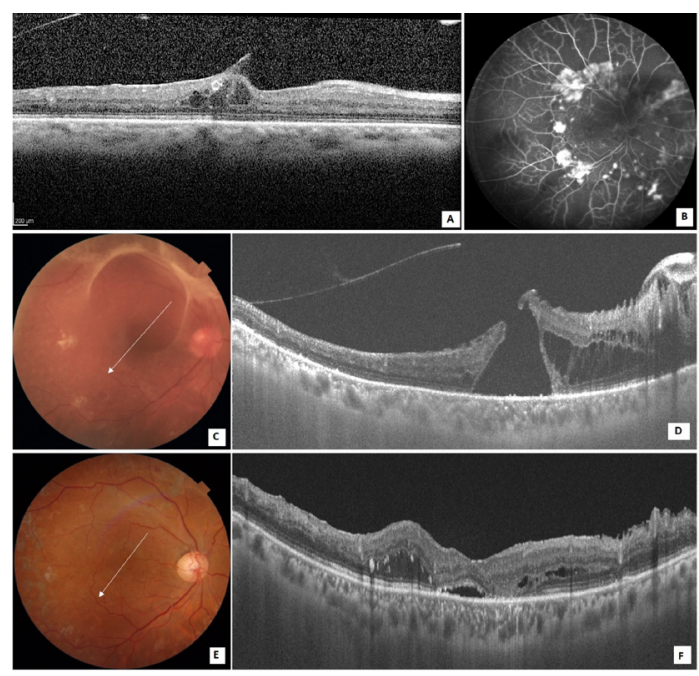

Figure 1 Optical coherence tomography (OCT) of right eye shows vitreomacular traction and few cystoid spaces (A). Fundus fluorescein angiography showing multiple areas of retinal neovascularisation and capillary nonperfusion (B). Colour fundus photograph (CFP) showing development of fibrous tissue along superotemporal arcade (C, white arrow depicts direction of OCT scan). OCT shows macular hole and retinal oedema (D). CFP after vitrectomy shows resolution of retinopathy and membranes ( $E$, white arrow depicts direction of OCT scan). OCT shows closure of macular hole, macular oedema and outer retinal lucency (F).

\section{Learning points}

- Macular hole formation can occur after panretinal photocoagulation in proliferative diabetic retinopathy with vitreomacular traction.

- Increase in fibrosis and macular oedema are probably contributory factors.

month later. Postoperatively, at 1 month, BCVA improved to 20/40, media was clear and PDR had regressed (figure 1E). OCT showed type 1 macular hole closure though mild oedema was noted. The clinical picture was maintained till 6 months of follow-up.

Lack of symptoms of macular involvement and good BCVA prompted us to proceed with PRP in spite of presence of VMT and mild macular oedema. Ablation of ischaemic retina with PRP leads to downregulation of vascular endothelial derived growth factor and promotes fibrosis. ${ }^{1}$ The increasing fibrosis along with VMT may have contributed to the formation of FTMH in this case. Though macular oedema is a common complication following PRP in the setting of PDR, formation of FTMH has not been described to the best of our knowledge. ${ }^{2}$ Intraretinal exudation combined with increased VMT may also contribute towards formation of FTMH once the oedema increases following PRP in such cases. ${ }^{3}$ The release of VMT with formation of macular hole and cystoid spaces at edges would indicate likelihood of spontaneous closure of macular hole. Patient was observed for 1 month but no change was observed which may be because of retinal changes in diabetics. Because of persistent decreased vision, decision to perform vitrectomy was taken. Vitrectomy resulted in closure of hole and improvement in BCVA. ${ }^{4}$ This case highlights an unusual complication of PRP in a patient with PDR and VMT.

Contributors The criteria for authorship have been met and each author believes that the manuscript represents honest work. The manuscript has been reviewed and approved by all named authors.

Funding The authors have not declared a specific grant for this research from any funding agency in the public, commercial or not-for-profit sectors.

Competing interests None declared.

Patient consent for publication Obtained.

Provenance and peer review Not commissioned; externally peer reviewed.

ORCID iD

Abhidnya Surve http://orcid.org/0000-0003-3719-4112 
Images in...

\section{REFERENCES}

1 Aiello LP. Angiogenic pathways in diabetic retinopathy. N Engl J Med 2005;353:839-41.

2 Diabetic Retinopathy Clinical Research Network, Brucker AJ, Qin H, et al. Observational study of the development of diabetic macular edema following panretinal (scatter) photocoagulation given in 1 or 4 sittings. Arch Ophthalmol 2009;127:132-40.
3 Brazitikos PD, Stangos NT. Macular hole formation in diabetic retinopathy: the role of coexisting macular edema. Doc Ophthalmol 1999;97:273-8.

4 Kurihara T, Noda K, Ishida S, et al. Pars plana vitrectomy with internal limiting membrane removal for macular hole associated with proliferative diabetic retinopathy. Graefes Arch Clin Exp Ophthalmol 2005;243:724-6.

5 Cooper BA, Shah GK, Sheidow TG, et al. Outcome of macular hole surgery in diabetic patients with nonproliferative retinopathy. Retina 2004;24:360-2.

Copyright 2021 BMJ Publishing Group. All rights reserved. For permission to reuse any of this content visit

https://www.bmj.com/company/products-services/rights-and-licensing/permissions/

BMJ Case Report Fellows may re-use this article for personal use and teaching without any further permission.

Become a Fellow of BMJ Case Reports today and you can:

- Submit as many cases as you like

Enjoy fast sympathetic peer review and rapid publication of accepted articles

- Access all the published articles

Re-use any of the published material for personal use and teaching without further permission

\section{Customer Service}

If you have any further queries about your subscription, please contact our customer services team on +44 (0) 2071111105 or via email at support@bmj.com.

Visit casereports.bmj.com for more articles like this and to become a Fellow 